\title{
Organisational Power, Cohesiveness and Culture of Taiwan's Cosmetology Industry
}

\author{
Mingchang Wu, Deni Danial Kesa* and Chen-Ju Ko
}

\begin{abstract}
Manuscript type: Research paper

Research aims: This study aims to examine the influential paths and internal relationships of organisational power, organisational culture and organisational cohesiveness.

Design/Methodology/Approach: The Analysis of Moment Structures (AMOS) is used to analyse the survey data collected from 222 practitioners who are from five cosmetology industries based in Taiwan.

Research findings: This study reveals that: (1) both organisational power and organisational culture individually creates significant impacts on organisational cohesiveness, and (2) organisational culture plays an important role as a mediator between organisational power, and organisational cohesiveness.

Theoretical contribution/Originality: This finding encourages the need for more positive organisational culture to be built to enhance organisational cohesiveness which contributes to the achievement and performance of both the individuals and the organisations at large.
\end{abstract}

\footnotetext{
* Corresponding author: Deni Danial Kesa is a Lecturer at the Vocational Education Program, Universitas Indonesia. Email: d.danial@ui.ac.id

Mingchang Wu is a Professor at the Graduate School of Vocational and Technology Education, National Yunlin University of Science and Technology, Taiwan. Email: wumc@yuntech.edu.tw Chen-Ju Ko is a Lecturer at the National Taichung University of Science and Technology, Taiwan. Email: chenjuko@gmail.com

Acknowledgement: This research was funded by the Ministry of Research, Technology and Higher Education, Republic of Indonesia - Grant Number: NKB.1676/UN2.R3.1/ HKP.05.00/2019.
} 
Practitioner/Policy implications: The interactive factors' effect overwhelms the single-factor effect, where individuals develop their organisational cohesiveness, even if each single factor functions separately. In reality, organisational culture needs to be the first priority factor to be developed in a workplace so as to build cohesiveness.

Research limitations/Implications: This study is conducted based on a fundamental assumption, hence the limitation lies in that the surveyed sample may or may not fully understand the question/ items provided in the questionnaire. This could affect the level of honest answers revealed through their perceptions. Future studies may consider taking the qualitative approach.

Keywords: Cosmetology Industry, Organisational Power, Organisational Culture, Organisational Cohesiveness

JEL Classification: L66, L2, D91

\section{Introduction}

Organisational cohesiveness is referred to as a group's propensity to remain unified towards embracing the group's objectives, or needs. Literature (Banwo, Du, \& Onokala, 2015; Loty, 2014) has emphasised on how organisational cohesiveness enhances organisational performance. Team members with high levels of cohesiveness support one another; they work together towards attaining shared goals and visions. They are also more likely to defend the group norms. Because of this, individuals within the group carry a sense of security and belonging, thus they experience lower levels of stress, and greater job satisfactions. This leads to higher productivity. In contrast, poor organisational cohesiveness leads to high turnover rate since members lack the sense of security and belonging. Organisational cohesiveness has become increasingly important in today's environment, considering that employees face numerous challenges in performing work tasks. This inevitably, creates high pressure at the workplace. Under this circumstance, most employees would feel exhausted and drained. To promote positive emotions among employees, and to enhance their relationships with each other, a positive workplace with harmonious cohesiveness is necessary. It helps employees to renew their energy. Today, organisational cohesiveness is one of the attributes of a contemporary workplace (Devaraj \& Jiang, 2019) where the focus is more on teamwork. This idea is aimed at developing better organisational achievements and performance quality. 
A small body of research (Scott \& Davis, 2015; Tannenbaum, 2013) argued that the organisations' leadership behaviour may be a crucial factor affecting the development and maintenance of organisational cohesiveness. In the business world, executive administrators or leaders are habitually empowered, and trained with the legitimate, and coercive power of demonstrating a bureaucratic authority. This is also referred to as referent power or reward power; it is presented to human concerns as a step to enable them to fulfil organisational missions, thereby building organisational hierarchy (Flamholtz, 2001). These organisational powers are exhibited, and exercised for the organisation's effective administration as well as to reap business profits, an ultimate destination (Lucas \& Baxter, 2012). Although the power exercised by the leader is regarded as a factor that may bring benefits to a team, such as the accomplishment of goals, and a more cohesive team environment, this relationship is argued to be non-linear, and that it could also be influenced by other factors such as organisational culture (Flamholtz, 2001).

In the workplace environment, some organisations perceive that power has an important effect on others, hence it is appropriate and motivating. Nonetheless, there are different types of power. Organisations that practice bureaucratic culture, for instance, may prefer leaders who have a strong tendency to control situations, dominate interactions, and exercise directive behaviours and close supervision (Hummel, 2014). In this type of organisation, leaders normally put employees in a dependent role, with specifications as to how they should complete their tasks. In contrast, organisations with a supportive culture have leaders who are more inclined in holding the co-workers or subordinates responsible for the end results, yet leaving them the liberty to execute their tasks in the way they chose to. In this regard, organisational culture could be a dominant factor influencing the effect of power as well as organisational cohesiveness.

Motivated by these arguments, the current study aims to contribute to the growing body of knowledge by examining the relationship between organisational power, organisational culture and organisational cohesiveness. More specifically, this study explores the direct effect of organisational power on organisational cohesiveness and organisational culture. It also examines the mediating effect of organisational culture on the relation between organisational power and organisational cohesiveness. To determine the interactions of these three variables, we will focus on the Taiwanese cosmetology industry which has been developing prosperously in the last three decades. 
In Asian countries, such as Taiwan, leaders tend to exercise more power and to act with more authority when compared to western leaders (Aycan \& Kanugo, 2002). In that regard, Asians are also more prone towards showing "authority" rather than "rules", and the person holding the power is trusted for his/her knowledge, expertise and achievement. In addition, some scholars (Liu, Chen, \& Holley, 2017) argued that the management philosophy and organisational culture have been rooted in and guided by Confucianism, more specifically, the concept of guanxi, which is a social concept prevailing in the Chinese community. This concept relies on personal relationships, loyalty, and modesty of the in-group community (Silverthorne, 2004). This unique culture is expected to lead to a different appreciation and prevalence of organisational power and cohesiveness.

The remainder of this paper is organised as follows: Section 2 discusses the literature on organisational power, culture and cohesiveness done in the past so as to develop the hypotheses. Section 3 describes the research methodology employed. Section 4 presents the empirical results and Section 5 concludes.

\section{Literature Review}

\subsection{Organisational Power}

Organisational power is extensively implemented to ensure cohesiveness, stability and administrative effectiveness in various organisations (Scott \& Davis, 2015; Tannenbaum, 2013), and there are various definitions of organisational power. It could be defined as: (1) the ability the organisation possesses so as to utilise all the mandatory resources, such as financial support, position promotion and others, in favour of organisation development (Pfeffer, 2013); (2) the authority which superiors hold to exercise control over a person or a team for the fulfilment of job missions, and/or their personal intentions (Rong, Yang, \& Ma, 2017; Ward, 2016); (3) the ability which team leaders embrace so as to influence the group of human resources to work towards achieving organisational objectives; and (4) the ability of superiors to manipulate other people's behaviours or attitudes (Lucas \& Baxter, 2012).

Organisational power is the force, authority or ability stemming from organisations and/or organisational hierarchies which drive their members to accomplish something as requested, or to behave according to organisational core values. It is also interpreted and highly exploited 
depending on the personality characteristics of those in authority and in settings where the power is utilised (Norris, 2009; Ward, 2016). Superiors can achieve both their own goals and those of their companies by recognising that organisations are essentially a system and structure of power, and thus knowing how to manage with power is important (Pfeffer, 2013). Scholars (Oc \& Bashshur, 2013; Kelley, 2015) have recognised the wide varieties of power which can be exercised and exploited in organisations. These varieties of powers include coercive power, referent power, appreciative power, legitimate power and reward power. The exercise and implementation of these organisational powers are usually determined by their inherent climates, administrative strategies and members' performance. This means that these powers are highly correlated with their culture and the internal relationship among team members (Harper, 2015; Lawrence, Mauws, Dyck, \& Kleysen, 2005).

\subsection{Organisational Culture}

In the business world, organisational culture is defined as a set of shared mental assumptions that guides the interpretation and action within organisations. This is achieved by defining the appropriate behaviours for various situations (Folch \& Ion, 2009; Merton, Froyd, Clark, \& Richardson, 2009; Slater, Olson, \& Finnegan, 2010). Organisational culture provides the implicit, unwritten, or unspoken guidelines for members to follow. It reduces collective uncertainties and may even create social classism for organisational harmony (Cameron \& Quinn, 2006; Chang \& Lu, 2007).

Organisational culture is of three typical types: (1) innovative culture that supports the creation of new ideas and the implementation of these ideas (Kor \& Mesko, 2013), (2) supportive culture that can promote a pleasant organisation advocating its members to work with friendliness and reciprocal affection (Nancarrow et al., 2013), and (3) bureaucratic culture where leadership provides a coherent, direct and certain instructions to the organisation's members so as to achieve its goals (Hummel, 2014). Different culture creates different effects on the organisation members. For instance, innovative culture will foster employees into proactively generating new ideas and innovative inventions; a supportive culture will increase comfort, trust and cohesion among the staff, as if they are family members while a bureaucratic culture will be more effective in an emergency situation, but it will create 
resistance among its subordinates if it is run by well-connected but incompetent people (Hellriegel, Jackson, \& Slocum, 2002).

\subsection{Organisational Cohesiveness}

Organisational cohesiveness is recognised as an essential element for team operations and organisational success (Rhee, Zhao, Jun, \& Kim, 2017; Stashevsky \& Koslowsky, 2006). It can be defined in a variety of ways such as: (1) a dynamic process which keeps team members united for organisational goals and team harmony (Al-Rawi, 2008), (2) a core component of organisational operation (Abid, Gulzar, \& Hussain, 2015); and (3) an attractiveness with which an organisation attracts its members to stay in hunger, and to dedicate to the fulfillment of personal goals in the organisation (Chen, Tang, \& Wang, 2009). Based on this, it can be concluded that organisational cohesiveness is the solidarity among organisation members and leaders with the subordinates. This fosters higher individual and collective motivation achievements.

Organisational cohesiveness is highly expected to: (1) inspire members' recognition to their organisations with obedience, in accordance to organisational decrees (Al-Rawi, 2008), (2) invigorate organisational members' loyalty in order to decrease employees' turnover rate (Sun, Ayoun, \& Calhoun, 2013), and (3) encourage all members to dedicate themselves to the organisation with mutual accreditations, and core values (Liu et al., 2017). Organisational cohesiveness not only plays the imperative role to reciprocally attract team members, but also to enhance the core values for organisational operations (Stashevsky \& Koslowsky, 2006) as well as effectively encourage members to fully cooperate for organisational goals. Organisational cohesiveness also contributes to individual missions graced with dignity, and harmony, besides increasing individual performance, and organisational achievements (Banwo et al., 2015). Due to organisational cohesiveness, leaders and team members are devoted to enhancing organisational cohesiveness for a pleasant employment environment, and reciprocal productiveness (Harhara, Singh, \& Hussain, 2015).

\subsection{Hypotheses Development and Research Framework}

The impact of organisational power on organisational cohesiveness has been studied (Banwo et al., 2015; Hatch, 2018). Leaders may use organisational power to lead the whole team in achieving organisational 
goals, or they may use their directive behaviour to supervise and control team members closely so as to ensure that they focus strongly on one common target. This type of organisational power is noted to be more effective when the subordinates are less matured in terms of motivation and performance, and so, less productive. In other cases, leaders may practice the appreciative power where they demonstrate their affection towards subordinates' preferences, needs and welfare, thereby providing a psychologically supportive environment to ensure cohesiveness. Under such conditions, we expect that employees would demonstrate cohesive behaviours in task completion. Based on these arguments, it is hypothesised that:

$\mathrm{H}_{1}$ : Organisational power is positively related to organisational cohesiveness.

Organisational cultures are not uniform nor static; it continuously changes and evolves over time (Weick \& Quinn, 1999). A changing culture means changing people's minds, behaviours and attitudes. Some scholars (e.g. Schein, 1992) have highlighted the role of organisational power in determining and changing organisational culture. It has been mentioned that change in organisations cannot be made by focusing on its culture directly. Indeed, the way leaders exercise their power on the employees may influence the changes of the organisational culture. For example, leaders who want to create a culture of bureaucracy are found to promote legitimate powers more since this focusses on a chain of commands, detailed structures and definitions, thereby ensuring more control. Similarly, an organisation that values innovative culture would be associated with referent power, and expert power. This is because under the innovative work culture, employees look to the superiors or leaders for knowledge or skills. Attention, respect and admiration of others, as practiced by leaders, would help to stimulate innovations (Dokko, Kane, \& Tortoriello, 2014; Wang, Rodan, Fruin, \& Xu, 2014). Based on these arguments, it is further hypothesised that:

$\mathrm{H}_{2}$ : Organisational power is positively related to organisational culture.

Organisational culture affects organisational cohesiveness through the establishment of actions, norms and the standard policies and procedures which guide the employees' action and behaviour (Shaner, Beeler, \& Noble, 2016). For example, employees under the innovative and supportive organisational culture are found to be more risk tolerant; 
they view the occasional failures as part of the learning process. Such an environment may be associated with organisational cohesiveness since employees under this culture feel more liberated in expressing their ideas and sharing information with others, in pursuit of organisational goals. Under this type of organisational culture, employees are expected to demonstrate more cohesive behaviours in completing tasks and in their interpersonal communications (Chen et al., 2009; Wendt, Euwema, \& Van Emmerik, 2009). Based on these arguments, it is hypothesised that:

$\mathrm{H}_{3}$ : Organisational culture is positively related to organisational cohesiveness.

The current study argues that organisational power is important for organisational cohesiveness, and that organisational power and organisational cohesiveness might be influenced by organisational culture. Some organisational cultures may view and evaluate power and its effect as more important than other organisational cultures. Under the bureaucratic organisational culture, employees may perceive legitimate power to be more appropriate and motivating since it emphasised on giving the chain of commands, a detailed structure and definitions, thereby ensuring more control. When employees are strongly influenced by how leaders exercise their power, they may also develop positive evaluations of the leaders' behaviours. This would make them more cohesive and less likely to resist working as a team. In contrast, employees under the supportive culture may value appreciative powers more, and so be more willing to work cooperatively as a team, on the condition that they perceive the leaders to be sensitive to their needs and welfare. They, however, may resist to work as a team if they perceive the leaders to be dominant, and controlling their interactions and task completions. Based on these arguments, it is hypothesised that:

$\mathrm{H}_{4}$ : Organisational culture mediates the relationship between organisational power and organisational cohesiveness.

Based on the literature review and the hypotheses developed, the following research framework was formulated, as shown through Figure 1.

\section{Methodology}

This study is quantitative in nature. It uses the survey questionnaire to measure the variables which were adapted from previous literature. Organisational power was measured using 29 items which were 


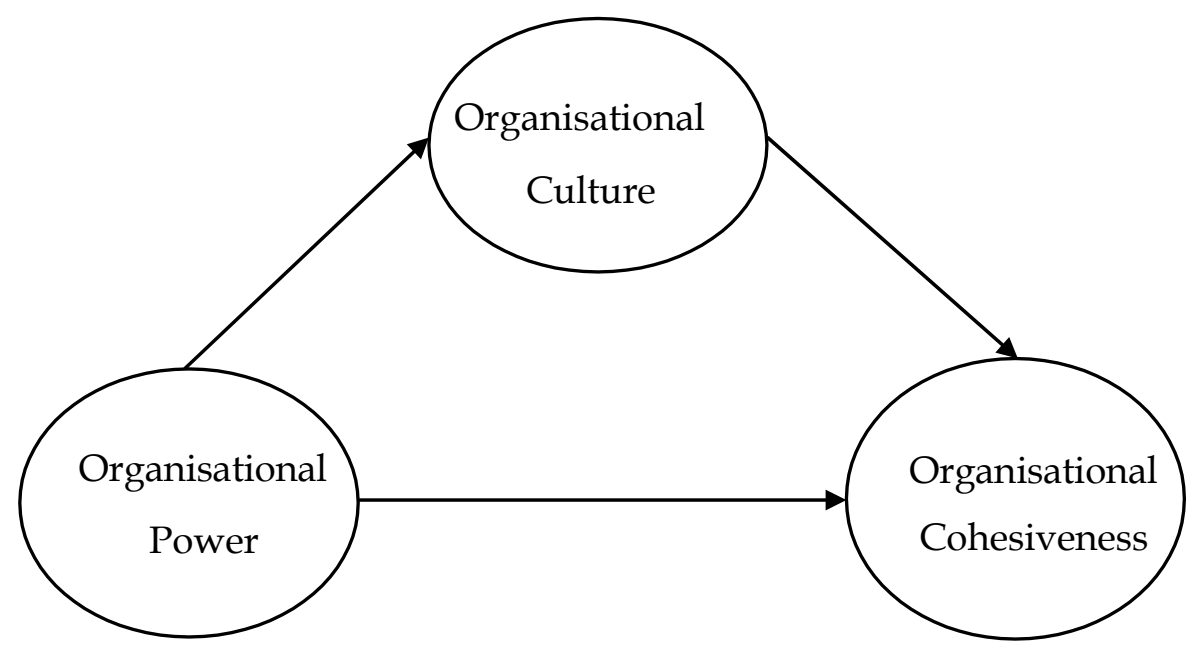

Figure 1: The Conceptual Framework

adapted from Kipnis, Schmidt and Wilkinson (1980). These items evaluate to what extent organisational leaders exercise their powers through coercive power, referent power, appreciative power, legitimate power and reward power. Based on Wallach (1983) and Wu and Lin (2010), this study adapted 12 items to measure organisational culture. These items evaluate the degree of organisational culture practised in terms of innovative, supportive or bureaucratic culture. Organisational cohesiveness was measured using 16 items which were adapted from Carron, Widmeyer and Brawley (1985). These items measure organisational cohesiveness in four domains which include interpersonal affinity, task cooperation, interpersonal attraction and operation adjustment. All the items used in this study were then translated by team researchers into Chinese, without changing the contents and meanings of the questions.

Prior to the actual data collection of the main study, a pilot test was conducted to establish the content and face validity of the instrument used. We randomly selected 120 samples from individuals/ employees who were engaged in the Taiwanese cosmetology industry. After two follow-ups and several emails, a total of 108 questionnaires were retrieved ( $90 \%$ returned rate), with six being excluded due to incompleteness. Of the 108 respondents, 33 per cent of them are located in Northern Taiwan, 35 per cent are from Central Taiwan, and 33 per cent are from Southern Taiwan. The pilot data collected are further 
analysed for scales reliability using Cronbach's alpha. The results indicate that all the variables - organisational power, organisational culture and organisational cohesiveness carry values of $0.95,0.79$ and 0.79 , respectively. Since these values are above the acceptable value of 0.6 , it is safe to say that the items used in this study are reliable.

Following the pilot study, we further conducted a larger empirical data collection. The target population of this study are employees in the Taiwan cosmetology industry. In this study, we first drew a list of the cosmetology companies that were registered with the Taiwan trade organisation. Based on this list given by the Taiwan trade organisation, 120 companies were identified. The companies were requested to participate in this study and their selection was based on random numbers. Relevant information regarding the project was forwarded to the Human Resource (HR) managers. Prior to the data collection, permission to conduct the study was requested from the human resource manager and the top management of the company. Three hundred questionnaires were then distributed to the respondents, who were given time (one week) to complete the questionnaires before a follow up (Sekaran \& Bougie, 2016). Two weeks following the distribution of the questionnaires, two follow-ups via telephone call were made. Of the 300 questionnaires distributed, 222 usable questionnaires were retrieved, indicating a response rate of 74 per cent. Table 1 depicts the demographic profiles of the respondents. Majority of the respondents are below 35 years old, possess diploma degree, work in the production section, and have less than 10 years of job experience.

\section{Results}

\subsection{Reliability and Validity}

This study performed the descriptive analysis so as to analyse the mean and standard deviations of the variables. The descriptive analyses reveal that the three variables are all highly valued components in the workplace (Organisational Power $\mathrm{M}=3.81$, Organisational Culture $M=3.85$, and Organisational Cohesiveness $M=3.85$ ). This study performed the measurement analysis by using an adequate model, with the coefficient of determination to another criterion for checking the adequacy to examine the convergent validity and the discriminant validity, shown in Table 2.

As depicted in Table 2, all the items that were tested fulfilled the threshold values (factor loadings $>0.4$, average variance extracted 
Table 1: Demographic Profile of Respondents

\begin{tabular}{lrc}
\hline Demographic Characteristics & Frequency & Percentage (\%) \\
\hline Age & 102 & 45.9 \\
Under 35 & 77 & 34.7 \\
$35-45$ & 31 & 14.0 \\
$46-54$ & 12 & 5.4 \\
Over 55 & & \\
Education & 112 & 50.4 \\
College Diploma & 62 & 28.0 \\
Bachelor Degree & 5 & 2.3 \\
Post Graduate & 43 & 19.3 \\
Professional Qualification & & \\
Job Specialisation & 28 & 12.6 \\
R\&D & 31 & 14.0 \\
Business Administration & 28 & 12.6 \\
Marketing & 18 & 8.1 \\
Finance & 117 & 52.7 \\
Production Section & & \\
Job Experience & 70 & 31.5 \\
Under 2 years & 59 & 26.6 \\
3-6 years & 72 & 32.4 \\
5-9 years & 21 & 9.5 \\
More than 10 years & & \\
\hline
\end{tabular}

Table 2: Convergent Validity Test

\begin{tabular}{lccc}
\hline Variable & Factor loading & CR & AVE \\
\hline A. Organisational power & & 0.94 & 0.75 \\
A1: Coercive power & $.65-.82$ & 0.89 & 0.53 \\
A2: Referent power & $.74-.83$ & 0.90 & 0.62 \\
A3: Appreciative power & $.70-.83$ & 0.90 & 0.59 \\
A4: Legitimate power & $.63-.70$ & 0.82 & 0.44 \\
A5: Reward power & $.65-.77$ & 0.83 & 0.50 \\
B. Organisational culture & & 0.76 & 0.52 \\
B1: Innovative culture & $.50-.69$ & 0.73 & 0.40 \\
B2: Supportive culture & $.47-.84$ & 0.76 & 0.47 \\
B3: Bureaucratic culture & $.38-.75$ & 0.67 & 0.36 \\
C. Organisational cohesiveness & & 0.81 & 0.52 \\
C1: Interpersonal affinity & $.54-.86$ & 0.77 & 0.53 \\
C2: Task cooperation & $.50-.89$ & 0.82 & 0.55 \\
C3: Interpersonal attraction & $.42-.80$ & 0.71 & 0.39 \\
C4: Operation adjustment & $.34-.61$ & 0.54 & 0.23 \\
\hline
\end{tabular}


$(\mathrm{AVE})>0.5$; composite reliability $(\mathrm{CR})>0.5)$. These results provide the evidence supporting convergent validity. Although there is an item under the interpersonal attraction, and bureaucratic culture that loaded below 0.4, this did not create an issue on convergent validity because it is a sub-construct which also have the AVE and CR values of more than 0.5 and 0.7, respectively. Therefore, the results demonstrate that the construct is able to describe greater than half of the variance of its variables. In this regard, we may conclude that the constructs are reliable and unidimensional (Bagozzi \& Yi, 1988; Anderson \& Gerbing, 1988).

The discriminant validity was then assessed using Fornell-Lacker's (1981) criterion. It appears that the square root of the average variance extracted (AVE) for a specific variable is higher than the correlation with other constructs, hence supporting the discriminant validity (Table 3). Based on the convergent and discriminant validity results, it could be deduced that all the items used are reliable and valid.

Table 3: Discriminant Validity Test

\begin{tabular}{|c|c|c|c|c|c|c|c|c|c|c|c|c|}
\hline & \multicolumn{5}{|c|}{$\begin{array}{c}\text { Organisational } \\
\text { Power } \\
(\mathrm{CR}=.94 \\
\mathrm{AVE}=.75)\end{array}$} & \multicolumn{3}{|c|}{$\begin{array}{c}\text { Organisational } \\
\text { Culture } \\
(\mathrm{CR}=.76 \\
\mathrm{AVE}=.52)\end{array}$} & \multicolumn{4}{|c|}{$\begin{array}{c}\text { Organisational } \\
\text { Cohesiveness } \\
(\mathrm{CR}=.81 \\
\mathrm{AVE}=.52)\end{array}$} \\
\hline & A1 & A2 & A3 & A4 & A5 & B1 & B2 & B3 & $\mathrm{C} 1$ & C2 & C3 & C4 \\
\hline A1 & .73 & & & & & & & & & & & \\
\hline A2 & $.75^{*}$ & .79 & & & & & & & & & & \\
\hline A3 & $.66^{*}$ & $.75^{*}$ & .77 & & & & & & & & & \\
\hline A4 & $.56^{*}$ & $.53^{*}$ & $.71^{*}$ & .66 & & & & & & & & \\
\hline A5 & $.46^{*}$ & $.56^{*}$ & $.66^{*}$ & $.51^{*}$ & .71 & & & & & & & \\
\hline B1 & $.30^{*}$ & $.30^{*}$ & $.27^{*}$ & $.21^{*}$ & $.42^{*}$ & .63 & & & & & & \\
\hline B2 & $.42^{*}$ & $.41^{*}$ & $.46^{*}$ & $.34^{*}$ & $.58^{*}$ & $.36^{*}$ & .69 & & & & & \\
\hline B3 & $.23^{*}$ & $.21^{*}$ & $.18^{*}$ & $.16^{*}$ & $.37^{*}$ & $.46^{*}$ & $.33^{*}$ & .60 & & & & \\
\hline $\mathrm{C} 1$ & $.46^{*}$ & $46^{*}$ & $.44^{*}$ & $.36^{*}$ & $.49^{*}$ & $.27^{*}$ & $.64^{*}$ & $.28^{*}$ & .73 & & & \\
\hline C2 & $.22^{*}$ & $.23^{*}$ & $.27^{*}$ & $.27^{*}$ & $.33^{*}$ & $.24^{*}$ & $.51^{*}$ & $.29^{*}$ & $.59^{*}$ & .74 & & \\
\hline C3 & $.32^{*}$ & $.21^{*}$ & $.32^{*}$ & $.28^{*}$ & $.32^{*}$ & $.26^{*}$ & $.36^{*}$ & $.23^{*}$ & $.42^{*}$ & $.54^{*}$ & .62 & \\
\hline C4 & $.23^{*}$ & $.18^{*}$ & $.24^{*}$ & $.14^{*}$ & $.23^{*}$ & $.23^{*}$ & $.38^{*}$ & .03 & $.33^{*}$ & $.29^{*}$ & $.40^{*}$ & .48 \\
\hline
\end{tabular}

Notes: ${ }^{*} \mathrm{p}<.05$. A1: Coercive power, A2: Referent power, A3: Appreciate power, A4: Legitimate power, A5: Reward power, B1: Innovative culture, B2: Supportive culture, B3: Bureaucratic culture, C1: Interpersonal affinity, C2: Task cooperation, C3: Interpersonal attraction, C4: Operation adjustment. Values in bold represent the square root of AVE. 


\subsection{Structural Model and Hypotheses Testing}

In the next step, the path model analysis was conducted using the structural equation modelling (SEM) to test the hypotheses. Figure 2 shows the path analysis between organisational power and organisational culture. The results indicate a positive significant path $(\beta=0.67, \mathrm{p}<$ $.05)$, thereby suggesting that organisational culture is influenced by organisational power. Hence, $\mathrm{H}_{1}$ is supported. Among all the components noted in organisational power, it appears that appreciative power is the most important factor for organisational culture $(\beta=0.90$, $\mathrm{p}<.05)$ while reward power is comparatively, the least concerned for organisational culture building $(\beta=0.71, \mathrm{p}<.05)$.

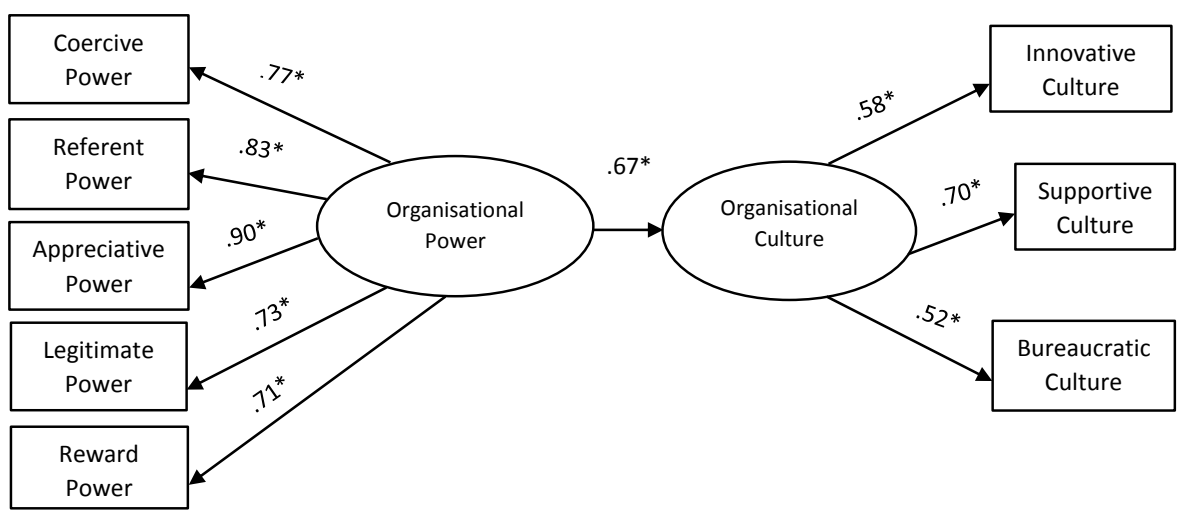

Figure 2: Path Analysis of Organisational Power on Organisational Culture

Figure 3 depicts the path analysis between organisational power and organisational cohesiveness. The statistics show that the relationship between the two variables is positively significant $(\beta=.92, \mathrm{p}<.05)$, showing that organisational power has an effect on organisational cohesiveness. Likewise, organisational cohesiveness is also highly influenced by appreciative power $(\beta=.92, \mathrm{p}<.05)$, but least affected by reward power $(\beta=.72, p<.05)$.

In this study, organisational culture is also found to have a positive impact on organisational cohesiveness $(\beta=.88, \mathrm{p}<.05)$ (Figure 4). Supportive organisational culture is the most imposing factor for building positive cohesiveness among team members $(\beta=.82, p<.05)$ whilst bureaucratic culture is the least $(\beta=.44, \mathrm{p}<.05)$. Among the components of organisational cohesiveness, interpersonal affinity seemed to be 


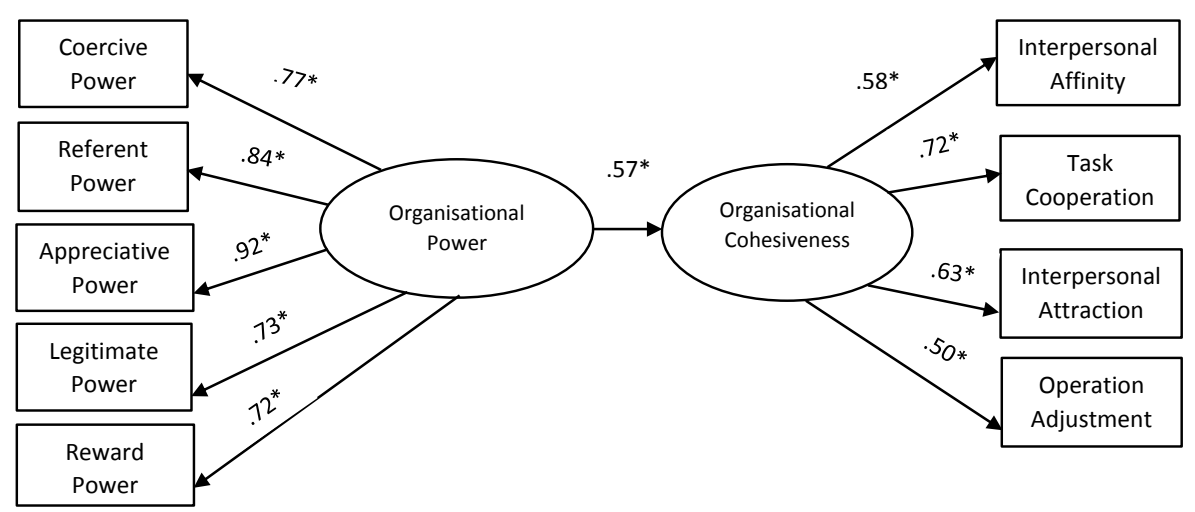

Figure 3: Path Analysis of Organisational Power on Organisational Cohesiveness

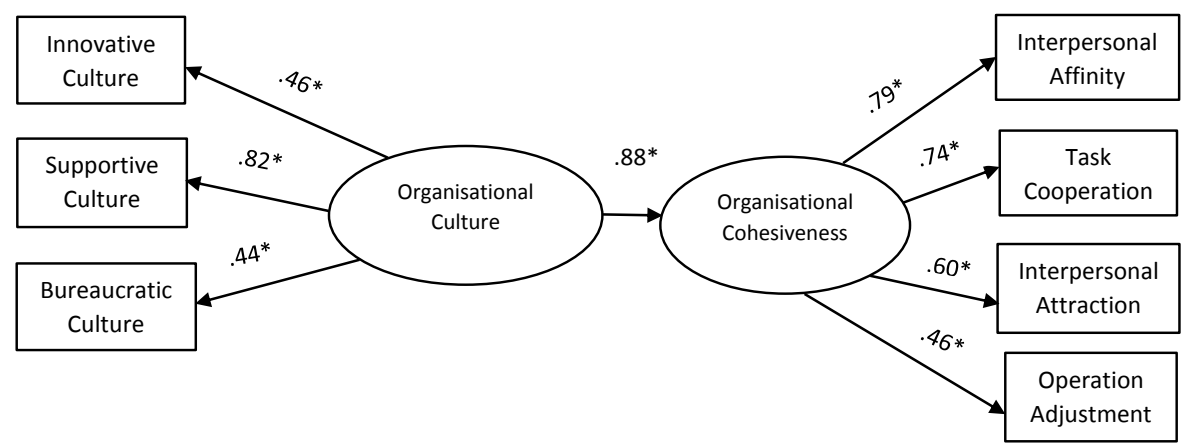

Figure 4: Path Analysis of Organisational Culture on Organisational Cohesiveness

the most sensitive to cultural influences $(\beta=.79, p<.05)$ whereas operational adjustment reacts the least, comparatively $(\beta=.46, \mathrm{p}<.05)$. Figure 4 illustrates.

This study has attempted to investigate the impact of organisational culture as a mediating factor between organisational power and organisational cohesiveness. As expected, the results reveal that organisational power does not directly impact on organisational cohesiveness in the realistic enterprise world $(\beta=.00)$ (Figure 5). The analysis had shown that the significant main effect of organisational power and organisational cohesiveness $(\beta=.92, p<.05)$ (Figure 3), 


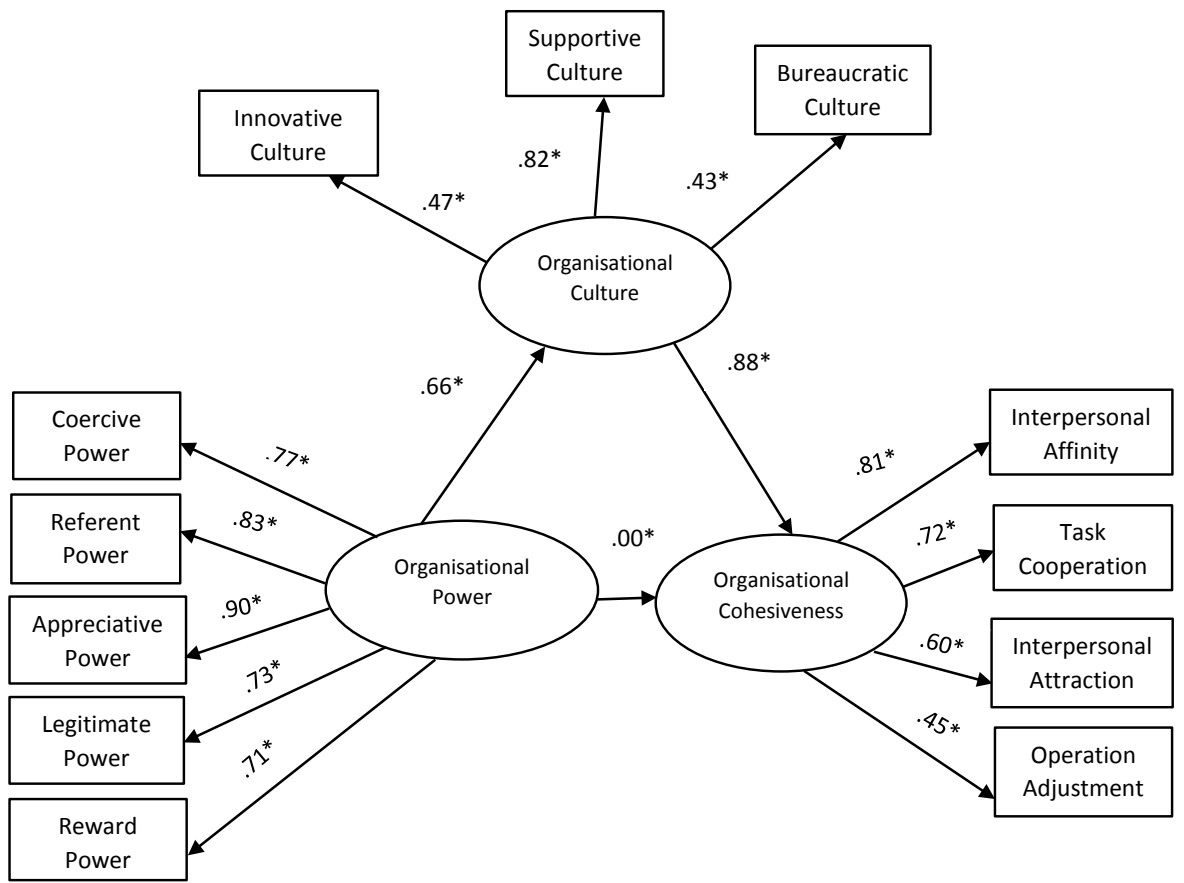

Figure 5: Examination of Mediating Role

became insignificant with the introduction of the indirect path through organisational culture. It appears that organisational power creates more impressive impact indirectly (through organisational culture) than directly on cohesiveness. Thus, organisational culture synthetically plays the mediator role in facilitating organisational power so as to influence its cohesiveness (Chen, et al., 2009).

\section{Discussion}

This study has explored the relations between organisational power and organisational cohesiveness in the context of the cosmetology industry in Taiwan. The observation of 222 employees working at the managerial level shows that the leaders exercise appreciative power considerably more than other types of organisational power. The observations also show that appreciative power is a pertinent factor influencing both the organisational culture and organisational cohesiveness. Conversely, the reward power component is the least important factor to influence 
both the organisational culture and organisational cohesiveness. This finding is consistent with Jayasingam, Ansari and Jantan (2010) who had found that reliance on referent power was less effective for improving the individual's performance in this knowledge-based era. The present findings offer interesting insights which also support the idea that the guanxi culture prevalent in Taiwan, make the leaders behave more supportively as they learn to appreciate their subordinates. Under this type of organisational power, an individual is not treated like a machine. In fact, the individual is perceived as someone who is able to develop his/her own knowledge and competencies due to his/her curiosity, and social experience sharing (Loty, 2014). While reward power is expected to provide the best outcome with new communication technologies and more social networking-have produced calls for new organisation theories for these new realities since it helps to manifest needs' fulfillment (Pfeffer, 2013), it is observed that the Taiwanese employees' value for intangible inputs such as sharing ideas and information are more important. This is not a surprising finding because these values are perceived to be more effective in encouraging people to continuously learn, and to produce favourable outcomes, including innovative behaviours, teamwork, and overall performance (Fauth, Bevan, \& Mills, 2009). Appreciation from the manager inspires the subordinate to feel free and empowered in making certain decisions. This result also shows that even though people in Asian countries are more inclined towards showing respect to leaders who act authoritatively (Aycan \& Kanungo, 2002), this situation may have changed today, or it may no longer exist in Asian countries which used to be rooted in the guanxi culture (one where the personal relationship dominates any decision). The leaders tend to be more participative rather than directive, currently.

In this study, organisational power, culture and cohesiveness have been proven to be highly correlated with each other on the individual basis. This creates an impact on another variable pair-wisely and simultaneously also show a higher institutional collectivism, future orientation, a humane orientation and a lower level of assertiveness. This could cause an interactive impact on the other variables. Previous studies (Bortolotti, Boscari, \& Danese, 2015; Rothaermel \& Hess, 2007) had shown that organisational culture played an influential role on organisational cohesiveness. This study, hereby confirms that organisational culture fully mediate the relationship between organisational power, and cohesiveness, in the context of the cosmetology industry in Taiwan. Organisational culture is a set of shared mental assumptions which 
guides the interpretation and action of members in the organisation by defining appropriate behaviours for various situations (Ravasi \& Schultz, 2006). It also provides the implicit, unwritten or unspoken, guidelines for its members to follow in the organisation. This helps to reduce collective uncertainties, and may even create social classism for organisational harmony (Chang \& Lu, 2007; Kim \& Lee, 2006). In the realistic employment world, organisational power cannot directly influence its cohesiveness unless it inspires the organisational culture which activates its crucial role in the mediation effect. Organisational culture plays an important role in the Taiwanese context, where much of the culture revolves around relationships and friendships developed over time. This has led to a strong sense of members' loyalty towards their organisations. Therefore, it is not surprising that the organisational culture affected the relationship between organisational power, and organisational cohesiveness.

\section{Conclusions and Implications}

This study contributes to the existing literature on organisational behaviour and leadership by providing evidence to show the role of organisational culture as a mediator; it influences the interactions between organisational power, and organisational cohesiveness. This finding thus confirms that a constructive organisational culture is important for cohesive teams. This dominates the sustainability, and synchronisation of the organisation. Focusing on the cosmetology industry in Taiwan, this study has highlighted the transformation of organisational power in Asia. Where previously power was more authoritative or directive, today, it is a more supportive or appreciative power and culture. These types of organisational power and culture are important because they can develop positive attitudes towards teamwork or cohesiveness.

The findings of this study suggest that leaders in the Taiwanese organisations need to exercise more open discussions and to offer more constructive criticisms in supporting their employees. Supportive managers are also perceived to be better leaders, hence they are more valued and respected by the Taiwanese employees, instead of those who are authoritative or give directives. Nonetheless, the directive or authoritative power may also be necessary for managers in order to perform his/her duties and tasks. Managers need to be aware of the effect such powers may have on organisational cohesiveness. Managers who limit their behavioural powers to a certain type or style only, may 
cause negative organisational cohesiveness. This implies that Taiwanese managers need to change the way they exercise their power. In practice, appreciative power comes from providing a conducive environment to the employees to identify their success story within themselves, to create what their lives might be in the future, to design the effective ways of achieving their dreams, and to ensure that they would implement these so as to accomplish the organisation's objectives (Shuayb, 2014). Based on this, it can be said that a leader in a profit-oriented organisation should be able to provide a space for the employees to mutually and reciprocally discuss the strategies which can improve their performance, through self-development inquiry. A leader in an organisation should utilise his/her powers properly, with circumspection, and with humanity and care for developing a positive work environment and cohesive teamwork in organisations. Thus, organisational cohesiveness is reconfirmed to be vulnerable, and susceptible to its environmental factors, suggesting that the individual in power needs to maintain positive organisational operations and core values, based on social and humanitarian principles.

The findings of this study verify that Taiwanese organisations, particularly the cosmetology industry, should be more aware of the employees' freedom and happiness, as this will link to the team development. For foreign or international firms that wish to invest in Taiwan, they should also take into consideration the significant influence of the types of organisational power and culture. An employee who is unhappy with the way power is exercised in the organisation may affect the productivity outcome. Thus, managers need to give more focus to these issues so as to avoid any misunderstanding.

This study offers an insight into the interactions between organisational power, organisational cohesiveness, and organisational power in the context of the cosmetology industry in Taiwan. Despite the substantial contributions this study provided, this study is also constrained by some limitations. First, the samples of this paper are confined to the employees from the cosmetology industry. Future research may extend on the population by including those from different industries. Second is that this study is exclusive, it only focuses on the cosmetology industry and only one Asian country, Taiwan. Future research may conduct a comparative analysis of the different ASEAN nations since different Asian countries have different dominant cultures and values, which may have some impact on the values and perceptions of the people. 


\section{References}

Abid, H.R., Gulzar, A., \& Hussain, W. (2015). The impact of servant leadership on organizational citizenship behaviors with the mediating role of trust and moderating role of group cohesiveness: A Study of public sector of Pakistan. International Journal of Academic Research in Business and Social Sciences, 5(3), 234-242.

Al-Rawi, K. (2008). Cohesiveness within teamwork: The relationship to performance effectiveness - case study. Education, Business and Society: Contemporary Middle Eastern Issues, 1(2), 92-106. http:/ /dx.doi.org/10.1108/ 17537980810890284

Anderson, J.C., \& Gerbing, D.W. (1988). Structural equation modeling in practice: A review and recommended two-step approach. Psychological Bulletin, 103(3), 411-423.

Aycan, Z., \& Kanungo, R. N. (2002). Cross-cultural industrial and organizational psychology: A critical appraisal of the field and future directions. In $\mathrm{N}$. Anderson, D.S. Ones, H.K. Sinangil, \& C. Viswesvaran (Eds.), Handbook of Industrial, Work, and Organizational Psychology (pp. 385-408). London: Sage.

Bagozzi, R.P., \& Yi, Y. (1988). On the evaluation of structural equation models. Journal of the Academy of Marketing Science, 16(1), 74-94. http://dx.doi. org/10.1007/BF02723327

Banwo, A.O., Du, J., \& Onokala, U. (2015). The impact of group cohesiveness on organizational performance: The Nigerian case. International Journal of Business and Management, 10(6), 146-158. http://dx.doi.org/10.5539/ijbm. v10n6p146

Bortolotti, T., Boscari, S., \& Danese, P. (2015). Successful lean implementation: Organizational culture and soft lean practices. International Journal of Production Economics, 160(February), 182-201. http://dx.doi.org/10.1016/ j.ijpe.2014.10.013

Cameron, K.S., \& Quinn, R.E. (2006). Diagnosing and changing organizational culture: Based on the competing values framework. San Francisco, CA: Jossey-Bass.

Carron, A.V., Widmeyer, W.N., \& Brawley, L.R. (1985). The development of an instrument to assess cohesion in sport teams: The group environment questionnaire. Journal of Sport and Exercise Psychology, 7(3), 244-266. http:/ / dx.doi.org/10.1123/jsp.7.3.244

Chang, K., \& Lu, L. (2007). Characteristics of organizational culture, stressors and wellbeing: The case of Taiwanese organizations. Journal of Managerial Psychology, 22(6), 549-568.

Chen, C-H.V., Tang, Y-Y., \& Wang, S-J. (2009). Interdependence and organizational citizenship behavior: Exploring the mediating effect of group cohesion in multilevel analysis. The Journal of Psychology: Interdisciplinary and Applied, 143(6), 625-640. http//dx.doi.org/10.1080/002239 80903218273

Devaraj, S., \& Jiang, K. (2019). It's about time-A longitudinal adaptation model of high-performance work teams. Journal of Applied Psychology, 104(3), 433447. http://dx.doi.org/10.1037/ap10000372 
Dokko, G., Kane, A.A., \& Tortoriello, M. (2014). One of us or one of my friends: How social identity and tie strength shape the creative generativity of boundary-spanning ties. Organization Studies, 35(5), 703-726. http:/ / dx.doi. org/10.1177/0170840613508397

Fauth, R., Bevan, S., \& Mills, P. (2009). Employee performance in the knowledge economy: Capturing the keys to success. Psychology Research and Behavior Management, 2(November), 1-12. http://dx.doi.org/10.2147/PRBM.S4216

Flamholtz, E.J. (2001). Corporate culture and the bottom line. European Management Journal, 19(3), 268-275. http://dx.doi.org/10.1016/S02632373(01)00023-8

Folch, M.T., \& Ion, G. (2009). Analyzing the organizational culture of universities: Two models. Higher Education in Europe, 34(1), 143-154. http:// dx.doi.org/10.1080/03797720902747132

Fornell, C., \& Larcker, D.F. (1981). Evaluating structural equation models with unobservable variables and measurement errors. Journal of Marketing Research, 18(1), 39-50. http:/ / dx.doi.org/10.2307/3151312

Harhara, A.S., Singh, S.K., \& Hussain, M. (2015). Correlates of employee turnover intentions in oil and gas industry in the UAE. International Journal of Organizational Analysis, 23(3), 493-504. http://dx.doi.org/10.1108/IJOA11-2014-0821

Harper, C. (2015). Organizations: Structures, processes and outcomes. New York, NY: Routledge.

Hatch, M.J. (2018). Organization theory: Modern, symbolic, and postmodern perspectives. United Kingdom: Oxford University Press.

Hellriegel, D., Jackson, S.E., \& Slocum, J.W. (2002). Managing: A competency-based approach. Mason, $\mathrm{OH}$ : Thomson South-Western.

Hummel, R.P. (2014). The bureaucratic experience: The post-modern challenge. New York, NY: Routledge.

Jayasingam, S., Ansari, M.A., \& Jantan, M. (2010). Influencing knowledge workers: The power of top management. Industrial Management $\mathcal{E}$ Data Systems, 110(1), 134-151. http:/ / dx.doi.org/10.1108/02635571011008443

Kelley, P.J. (2015). Deception among organizational leaders: Impacts on employee perceptions of supervisor credibility, power, and trust (Master's thesis, University of Tennessee). Retrieved from https://trace.tennessee.edu/cgi/ viewcontent.cgi?article $=4597 \&$ context $=$ utk_gradthes

Kim, S., \& Lee, H. (2006). The impact of organizational context and information technology on employee knowledge-sharing capabilities. Public Administration Review, 66(3), 370-384. http://dx.doi.org/10.1111/j.1540-6210.2006. 00595.x

Kipnis, D., Schmidt, S.M., \& Wilkinson, I. (1980). Intraorganizational influence tactics: Explorations in getting one's way. Journal of Applied Psychology, 65(4), 440-452.

Kor, Y.Y., \& Mesko, A. (2013). Dynamic managerial capabilities: Configuration and orchestration of top executives' capabilities and the firm's dominant 
logic. Strategic Management Journal, 34(2), 233-244. http://dx.doi.org/ $10.1002 /$ smj.2000

Lawrence, T.B., Mauws, M.K., Dyck, B., \& Kleysen, R.F. (2005). The politics of organizational learning: Integrating power into the 4I framework. Academy of Management Review, 30(1), 180-191. http://dx.doi.org/10.5465/ amr.2005.15281451

Liu, D., Chen, X.P., \& Holley, E. (2017). Help yourself by helping others: The joint impact of group member organizational citizenship behaviors and group cohesiveness on group member objective task performance change. Personnel Psychology, 70(4), 809-842. http://dx.doi.org/10.1111/peps.12209

Loty, J. (2014). The power of appreciative inquiry: A practical guide to positive change. Performance Improvement, 53(8), 45-48. http://dx.doi.org/10.1002/ pfi.21433

Lucas, J.W., \& Baxter, A.R. (2012). Power, influence, and diversity in organizations. The ANNALS of the American Academy of Political and Social Science, 639(1), 49-70.

Merton, P., Froyd, J.E., Clark, M.C., \& Richardson, J. (2009). A case study of relationships between organizational culture and curricular change in engineering education. Innovative Higher Education, 34(4), 219-233. http:// dx.doi.org/10.1007/s10755-009-9114-3

Nancarrow, S.A., Booth, A., Ariss, S., Smith, T., Enderby, P., \& Roots, A. (2013). Ten principles of good interdisciplinary team work. Human Resources for Health, 11(1), 19-30. http://dx.doi.org/10.1186/1478-4491-11-19

Norris, E. (2009). Leadership: Cultivating people skills. Review of Business Research, 9(4), 67-83.

Oc, B., \& Bashshur, M.R. (2013). Followership, leadership and social influence. The Leadership Quarterly, 24(6), 919-934. http://dx.doi.org/10.1016/j.leaqua. 2013.10.006

Pfeffer, J. (2013). You're still the same: Why theories of power hold over time and across contexts. The Academy of Management Perspectives, 27(4), 269-280. http://dx.doi.org/10.5465/amp.2013.0040

Ravasi, D., \& Schultz, M. (2006). Responding to organizational identity threats: Exploring the role of organizational culture. Academy of Management Journal, 49(3), 433-458. http:/ / dx.doi.org/10.5465/amj.2006.21794663

Rhee, J., Zhao, X., Jun, I., \& Kim, C. (2017). Effects of collectivism on Chinese organizational citizenship behavior: Guanxi as moderator. Social Behavior and Personality: An international journal, 45(7), 1127-1142. http://dx.doi. org/10.2224/sbp.6218

Rong, Y., Yang, B., \& Ma, L. (2017). Leaders' sense of power and team performance: A moderated mediation model. Social Behavior and Personality: An International Journal, 45(4), 641-656. http://dx.doi.org/10.2224/sbp.5662

Rothaermel, F.T., \& Hess, A.M. (2007). Building dynamic capabilities: Innovation driven by individual, firm and network level effects. Organization Science, 18(6), 898-921. http://dx.doi.org/10.1287/orsc.1070. 0291 
Schein, E.H. (1992). How can organizations learn faster? The problem of entering the Green Room. Sloan Management Review, 34, 85-92.

Scott, W.R., \& Davis, G.F. (2015). Organizations and organizing: Rational, natural and open systems perspectives. New York, NY: Routledge.

Sekaran, U., \& Bougie, R. (2016). Research methods for business: A skill building approach (7th ed.). West Sussex, UK: John Wiley \& Sons.

Shaner, M.B., Beeler, L., \& Noble, C.H. (2016). Do we have to get along to innovate? The influence of multilevel social cohesion on new product and new service development. Journal of Product Innovation Management, 33(S1), 148-165. http:/ / dx.doi.org/10.1111/jpim.12327

Shuayb, M. (2014). Appreciative inquiry as a method for participatory change in secondary schools in Lebanon. Journal of Mixed Methods Research, 8(3), 299307. http:/ / dx.doi.org/10.1177/1558689814527876

Silverthorne, C. (2004). The impact of organizational culture and personorganization fit on organizational commitment and job satisfaction in Taiwan. Leadership \& Organization Development Journal, 25(7), 592-599. http:/ / dx.doi.org/10.1108/01437730410561477

Slater, S.F., Olson, E.M., \& Finnegan, C. (2010). Business strategy, marketing organization culture, and performance. Marketing Letters, 22(3), 227-242.

Stashevsky, S., \& Koslowsky, M. (2006). Leadership team cohesiveness and team performance. International Journal of Manpower, 27(1), 63-74. http:/ /dx.doi. org/10.1108/01437720610652844

Sun, T., Ayoun, B., \& Calhoun, J. (2013). The effect of organizational commitment on word-of-mouth intentions in recruitment in China. Journal of Human Resources in Hospitality $\mathcal{E}$ Tourism, 12(2), 192-216. http://dx.doi. org/10.1080/15332845.2013.752711

Tannenbaum, A. (2013). Social psychology of the work organization (RLE: Organizations). New York, NY: Routledge.

Wallach, E.J. (1983). Individuals and organizations: The cultural match. Training and Development Journal, 37(2), 29-36.

Wang, C., Rodan, S., Fruin, M., \& Xu, X. (2014). Knowledge networks, collaboration networks, and exploratory innovation. Academy of Management Journal, 57(2), 484-514. http://dx.doi.org/10.5465/amj.2011.0917

Ward, J. (2016). Keeping the family business healthy: How to plan for continuing growth, profitability, and family leadership. New York, NY: Palgrave MacMillan.

Weick, K.E., \& Quinn, R.E. (1999). Organizational change and development. Annual Review of Psychology, 50(1), 361-386. http://dx.doi.org/10.1146/ annurev.psych.50.1.361

Wendt, H., Euwema, M.C., \& Van Emmerik, I.H. (2009). Leadership and team cohesiveness across cultures. The Leadership Quarterly, 20(3), 358-370. http:/ / dx.doi.org/10.1016/j.leaqua.2009.03.005

Wu, C.S., \& Lin, T.Y. (2010). Professional learning community. Journal of Education Research, 191, 125-126. 